\title{
Regulation of Education Market Access Based on Mixed Oligopoly Model*
}

\author{
Junlong Chen ${ }^{1}$ \\ Northeastern University at Qinhuangdao \\ Feifan $\mathrm{Mo}^{3}$ \\ Northeastern University at Qinhuangdao
}

\author{
Liuchang $\mathrm{Xu}^{2}$ \\ Northeastern University at Qinhuangdao
}

Zhiying Bian ${ }^{4}$

Northeastern University at Qinhuangdao

\begin{abstract}
Market access regulation is a necessary means to enhance the supply efficiency of education products. Thus, this paper builds a mixed oligopolistic market of a public school and several private schools, examines the impact of access regulation (i.e. the number of schools) on social welfare, and investigates the roles of the operating cost of schools with different natures and the externalities of education products. The research reveals the great boost of access regulation to the social welfare of the education market and the dependency of access regulation on both the operating cost of schools with different natures and the externalities of education products. Under the premise of fairness and efficiency, the government should establish a scientific market access standard, raise the threshold for market entry and prevent the disordered competition according to the externalities of different educational fields.
\end{abstract}

\section{Keywords}

Mixed Oligopoly • Access Regulation • Public School • Private School

\footnotetext{
* The work was supported by "the Fundamental Research Funds for the Central Universities" (NO. N172304021) and "the Natural Science Foundation of Hebei Province of China" (NO. G2018501047).

${ }^{1}$ Correspondence to: School of Business Administration, Northeastern University, Shenyang 110819, China; School of Economics, Northeastern University at Qinhuangdao, Qinhuangdao 066004, China. Email: shikuangzhiwang@ 126.com;

${ }^{2}$ School of Economics, Northeastern University at Qinhuangdao, Qinhuangdao 066004, China. Email: 15332165263@163.com

${ }^{3}$ School of Economics, Northeastern University at Qinhuangdao, Qinhuangdao 066004, China. Email: neuq724184935@163.com

${ }^{4}$ School of Management, Northeastern University at Qinhuangdao, Qinhuangdao 066004, China. Email: 15032389655@163.com.;

Citation: Chen, J. L., Xu, L. C., Mo, F. F., \& Bian, Z. Y, Regulation of Education Market Access Based on Mixed Oligopoly Model. Educational Sciences: Theory \& Practice, 18(5), 1389-1399. http://dx.doi.org/10.12738/estp.2018.5.036
} 
Education, traditionally viewed as a public product, has always attracted numerous financial supports from the government. With the rapid growth in population and education demand, the government can no longer support the huge education expenditures. As a result, there was a huge decline in the amount of education products and efficiency. Starting with "The Lighthouse in Economics" by Ronald H. Coase, scholars around the world have been exploring the possibility of private supply of traditional public goods, laying a theoretical basis for private education products. Currently, the education market worldwide is open to private capital to varying degrees. Private schools have become an integral part of the education system, providing education opportunities for many children (Baird, 2009; Dixon, 2012; Tooley, 2009; Tooley \& Dixon, 2006). The entire education market is featured by the mixture of state-owned capital and private capital.

Private capital is an effective means to solve the government failure in education. After entering the education market, private capital can make up for the lack of government funds and improve education efficiency through its flexible operating mechanism. However, private capital is profit-seeking in nature. To maximize the profit, the marginal cost is often set as equal to the marginal benefit during pricing. This goes against the universality and equity of education, especially elementary education. Hence, an education product with strong externalities should not be handed over to private capital for excessive marketization. If it must be marketized, the issue of equity ought to be considered to meet the education demand of the poor. For instance, it should be checked whether private schools could satisfy the education needs of the poor (Ashley, Mcloughlin \& Aslam, 2014; Härmä, 2011; Nguyen \& Raju, 2014; Tooley \& Dixon, 2006; Heyneman \& Stern, 2014). Compared to private schools, public schools ensure the education equity through the pursuit of the maximal social welfare, despite the lack of efficiency.

The existing studies on education mainly concentrate on two questions: whether education products should be marketized, and how should the government regulate the education market. Complete opposite answers have been put forward to these questions. In light of the high efficiency of private schools, some scholars consider marketization as an effective solution to the limited amount, poor quality and irrational allocation of public education resources (Phillipson, Shukla \& Joshi, 2008; Tooley, 2009). In contrast, some scholars treat private schools as a supplement to the education products supplied by the government and attempt to impose limits on the marketization of education. They worry that market-oriented education policies may sacrifice educational equity (Robertson and Dale, 2013; Menashy, 2014; Verger, Bonal \& Zancajo, 2016), and even call for a ban on for-profit education (Chumacero and Paredes, 2008; Ginsburg, Brady and Draxler, 2012; Hill \& Welsch, 2009). Chile, India and other countries maintain education equity by providing education vouchers or forcing private schools to offer education to low-income people. Moreover, many hold that strict legal regulation should be adopted to restrict the development of private schools and to keep the state as the provider of free education (Fielden \& LaRocque, 2009; Härmä \& Adefisayo, 2013; McLoughlin, 2013; Singh, 2015). of course, the governments of some developing countries are too incompetent and inefficient in regulation to solve the externalities of private schools (Baum, Cooper, R., \& Lusk-Stove, 2018). To sum up, there must be a limit on the market supply of education products, such that the provision could be completed smoothly through the coordination between government and the market. This limit is the problem to be discussed in this paper. 
The above analysis shows that the government should control the number of private schools in the education market, i.e. regulate the market access and find the optimal number. If there are fewer private schools than the optimal number, it will be impossible to leverage the advantages of private capital; otherwise, the education market will put profit over social equity. This paper aims to determine how should the government control the number of private schools in education market through access regulation, and maximize the social welfare through utilizing the comparative advantages of the government and the market.

\section{Method}

In general, the existing theoretical analyses on education market are still too shallow, owing to the lack of rigorous and scientific tools. To solve the problem, this paper employs the mixed oligopoly model to identify the optimal number of private schools in the education market. The traditional oligopoly theory tackles the competition between private companies for the maximum profit. By this theory, the real-world economic situation can be simulated accurately, provided that the companies only pursue the maximum profit. Nevertheless, the government, facing market failures, has created state-owned institutions to provide enough public goods. In this case, the economic situation can no longer be explained well by the traditional oligopoly theory. Based on the traditional theory, foreign scholars put forward the mixed oligopoly theory that explains the oligopolistic competition between state-owned and private institutions. The mixed oligopoly refers to the structure of a homogeneous or heterogeneous product market which triggers the competition between a few state-owned enterprises pursuing the maximal social welfare and private companies pursuing the maximal profit (Matsumura, 1998). The mixed oligopoly theory has become an effective tool to interpret the competition between state-owned and private organizations.

There are two completely opposite views on the efficiency of mixed oligopoly and pure oligopoly markets. One of the views is that the market should be fully privatized because state-owned property right will lead to low efficiency. (De Fraja \& Delbono, 1989) argues that a mixed oligopoly of a few private enterprises and one state-owned enterprises produces less social welfare than a pure oligopoly of only private enterprises. (Estrin \& Perotin, 1991) believes that state-owned enterprises, emphasizing political and economic targets over profit, perform poorly due to the weak governance arrangement. (Shleiefr \& Vishny, 1994) also agree with the superiority of private ownership over state ownership, and hold that the government tends to reap profit from enterprises for politicians and bureaucrats. These ideas are backed up by empirical evidence that government ownership has a negative impact on enterprise value (Megginson \& Netter, 2001). The other view is that stateowned property right, pursuing the maximal social benefit, is not necessarily less efficient than private oligopoly. (George \& La Manna, 1996) explored the efficiency of mixed oligopoly markets under asymmetric information, and determined the boundaries of inefficient privatization, effective public property right and efficiency privatization, and inefficient public property right. Based on the constant elasticity of substitution (CES) utility function, (Anderson, Palma \& Thisse, 1997) concluded that the pure oligopoly produces less social welfare than mixed oligopoly. 
The education market worldwide is a typical mixed economy. In other words, state-owned capital and private capital coexist in the market. Thus, the mixed oligopoly theory is more suitable for this market than the traditional oligopoly theory. Considering the current situation of the education market, the mixed oligopoly model can help with the design of realistic market demand function, the number of competitive subjects, and the utility function of each competitive subject. With these functions and parameters, it is possible to disclose the competitive behaviour and internal mechanism of education product providers with different natures, and identify the rational boundary between the government and market. Therefore, it is reasonable to apply the mixed oligopoly model to the mixed education market. Nonetheless, it is often assumed that the education products are private, without considering externalities, and that the social welfare function only involves the specific industry. These assumptions are not in line with the positive externalities of the education industry. Therefore, this paper probes deep into the access regulation of the education market, aiming to advance the theories in this field and expand the mixed oligopoly theory to high-externality market.

\section{Modelling}

In light of the research purpose, this paper sets up a mixed oligopoly competition model with multiple subjects based on the following hypotheses:

Hypothesis 1: There is an education market monopolized by public school. To increase the supply of education products, the government allows the entry of private capital, forming a competitive market involving $\mathrm{n}$ education agencies (1 public school and n-1 private schools). The public school is denoted as 1 and the private ones as $\mathrm{i}(\mathrm{i} \geq 2)$. The schools engage in Cournot competition for output. Let $\sum_{i=1}^{n} q_{i}$ be the total market output and $p=a-\sum_{i=1}^{n} q_{i}$ be the function of the total market output.

Hypothesis 2: The public and private schools have different utility functions. Private schools pursue the maximal profit, while the public school pursues the maximal social welfare. This means the public school can operate at a loss. Let $c_{1}=m q_{1}$ and $c_{i}=d q_{i}(i=2,3,4 \ldots n ; a>m>0 ; a>d>0)$ be the cost of stateowned school and private school, respectively, and $\pi_{1}=p q_{1}-c_{1}$ and $\pi_{i}=p q_{i}-c_{i}$ be the cost function of the public school and private schools, respectively.

Hypothesis 3: With obvious externalities, education products should not be supplied by the market only. Otherwise, the resulting positive externalities cannot be compensated. To reflect this feature, it is assumed that the social welfare function is $s w=r \sum_{i=1}^{n} q_{i} p-\sum_{i=1}^{n} c_{i}+c s(r \geq 1)$ for the external benefit generated by the education market. The value of the function is positively correlated with the level of externality. The consumer surplus is $c S=\frac{\left(\sum_{i=1}^{n} q_{i}\right)^{2}}{2}($ Singh \& Vives, 1984; Jain \& Pal, 2012).

Hypothesis 4: The government regulates the access of private schools to the market and determines whether to open the market and the degree of openness, i.e. the value of $n$.

Under the above hypotheses, two schools enter a two-stage dynamic sequential game. 
Stage 1: The government regulates the market access and determines the number of schools in education market $n$.

Stage 2: The schools derive the optimal outputs $q_{1}{ }^{*}$ and $q_{i}{ }^{*}(i=2,3,4 \ldots n)$ to maximize their utilities.

\section{Model Analysis}

\section{(1) Effect of $\mathbf{n}$ on sw}

The equilibrium output can be obtained from the Cournot competition between the schools in stage 2 of the game. Since school 1 pursues the maximal social welfare and the private schools the maximal profit, it is possible to derive the optimal outputs $q_{1}{ }^{*}$ and $q_{i}{ }^{*}(i=2,3,4 \ldots n)$. Let the partial derivatives of social welfare sw and private school profit $\pi_{i}$ be zero relative to output q:

$$
\begin{aligned}
& \frac{\partial s w}{\partial q_{1}}=r\left(p-q_{t}\right)-m+\stackrel{\substack{i=1 \\
n}}{n} q_{i}=r p+(1-r) \stackrel{\substack{i=1 \\
n}}{n} q_{i}-m=0 \\
& \frac{\partial \pi_{i}}{\partial q_{i}}=p-q_{i}-d=0, i=2,3,4 \ldots n
\end{aligned}
$$

The total equilibrium output and the equilibrium output of each education institution can be obtained from equations (1) and (2):

$$
\begin{aligned}
& \stackrel{\substack{i=1 \\
n}}{n} q_{i}=\frac{m-r a}{1-2 r} \\
& q_{1}^{*}=(n-1)(d-a)+\frac{m n-r a n}{1-2 r} \\
& q_{i}^{*}=\frac{(a-2 d) r-a+d+m}{2 r-1}, i=2,3,4 \ldots n
\end{aligned}
$$

According to equations (4) and (5), the output of private schools has nothing to do with the number of schools in the market, while the output of the public school is negatively correlated with that number. With the continued growth in that number, the public school has to reduce its output so that the private schools can continue with their production. This satiation is inconsistent with the traditional oligopoly competition, for the public school considers the benefits of other competitors in the market in addition to consumer surplus and its own benefit. Therefore, the number of schools in the market must be limited, or the public school will cease its production and even exit the market.

To ensure the positivity of the output and the number of private schools, the following formulas can be derived from equations (4) and (5):

$$
\begin{aligned}
& r a-2 d r-a+d+m>0 \\
& n<\frac{(a-d)(2 r-1)}{r a-2 d r-a+d+m}
\end{aligned}
$$

Substituting the social welfare sw into the above equations, we have: 


$$
S W=\frac{((4 n-4) r-2 n+2) d^{2}-2(n-1)((a+2 m) r-a) d+a^{2} r^{2}+2 a m(n-2) r-2\left((n-1) a-\left(n-\frac{1}{2}\right) m\right) m}{-2+4 r}
$$

Next, the effect of $n$ on sw can be obtained from stage 1 of the game, making it possible to determine the optimal number of private education institutions.

The partial derivative of sw relative to $\mathrm{n}$ can be obtained as:

$$
\begin{aligned}
& \frac{\partial s w}{\partial n}=\frac{(r a-2 d r-a+d+m)(d-m)}{1-2 r} \\
& \text { s.t. } r a-2 d r-a+d+m>0, n<\frac{(a-d)(2 r-1)}{r a-2 d r-a+d+m}
\end{aligned}
$$

Since $1-2 r<0$, the positivity/negativity of equation (9), as a determinant of the effect of $\mathrm{n}$ on sw, depends on that of $d-m$ :

If $\mathrm{d}>\mathrm{m}, \frac{\partial s w}{\partial n}<0$, i.e. $\mathrm{n}$ is negatively correlated with social welfare;

If $\mathrm{d}=\mathrm{m}, \frac{\partial s w}{\partial n}=0$, i.e. $\mathrm{n}$ is not correlated with social welfare;

If $\mathrm{d}<\mathrm{m}, \frac{\partial s w}{\partial n}>0$, i.e. $\mathrm{n}$ is positively correlated with social welfare.

To keep the output greater than zero, the value of $n$ must be constrained by equation (7). Otherwise, the private schools will exit the market. Assuming that $f(r, m)=\frac{(a-d)(2 r-1)}{r a-2 d r-a+d+m}$, it can be derived that $\frac{\partial f(m, r)}{\partial m}<0$ and $\frac{\partial f(m, r)}{\partial r}=-\frac{(a-d)(a-2 m)}{((r-1) a+(1-2 r) d+m)^{2}}$, i.e. the value range of $\mathrm{n}$ decreases with the increase of $\mathrm{m}$; the effect of $\mathrm{r}$ on the value range of $\mathrm{n}$ depends on the positivity/negativity of $a-2 m$.

Below is an example for the said effect. The $n$-sw relationship at different $m$ values was simulated by MAPLE with $\mathrm{a}=10, \mathrm{r}=1.2$ and $\mathrm{d}=1$. The results are presented in Figure 1 . Note that $\mathrm{a}=10$ and $\mathrm{d}=1$ are adopted for the subsequent analysis.

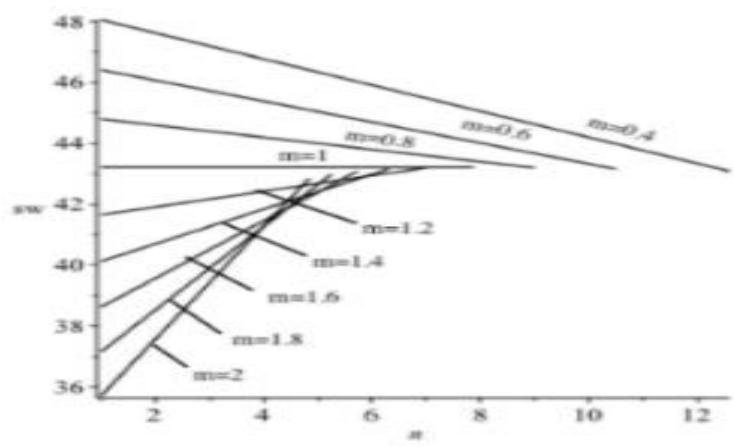

Figure 1. The n-sw relationship at different $m$ values

Similarly, the n-sw relationship at different $r$ values was simulated and plotted as Figure 2. 
As shown in Figures 1 and 2, it is learned that $r$ has no impact on the $n$-sw relationship, but could affect its value range. If $a-2 m>0$, the value of $r$ is negatively correlated with the value range of $n$; otherwise, the value of $r$ is positively correlated with the value range of $n$. Besides, $m$ directly bears on the $n$-sw relationship and the value range of $\mathrm{n}$ : with the increase of $\mathrm{m}$, the maximum value of $\mathrm{n}$ gradually declines, while the $\mathrm{n}$-sw correlation shifts from negative to positive.

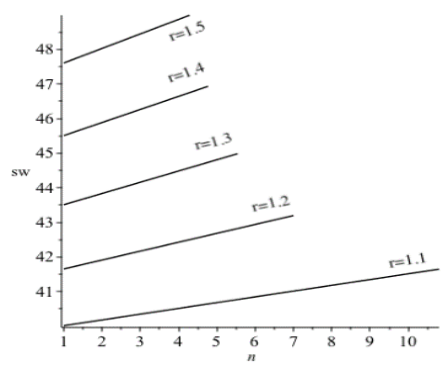

(a) $\mathrm{m}=1.2$

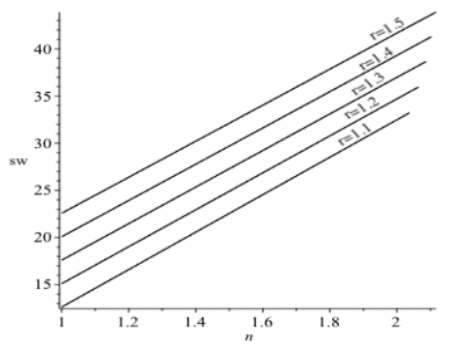

(b) $\mathrm{m}=5.5$

Figure 2. The n-sw relationship at different $\mathrm{r}$ values

Thus, we can get Proposition 1:

Proposition 1: If the public school is less efficient than private schools, the social benefit increases with the number of private schools in the market, and has nothing to do with the total number of schools; otherwise, the social benefit increases with the decline of the total number of schools in the market. With the growth in the value of $\mathrm{m}(a-2 m>0)$ or $\mathrm{r}$, the number of competing schools will decrease continuously without affecting the normal production; when $a-2 m>0$, there is a positive correlation between $\mathrm{r}$ and the value range of $\mathrm{n}$.

The meaning of the above proposition is as follows: The government must fully consider the production and profitability of private schools before regulating the access to the education market. If the private schools cannot make a profit or prevent losses, no private capital will enter the market even if the market is fully open. Moreover, the government should strictly control the number of private schools in the market, and consider the efficiency of the public school in the access regulation. If the public school is very efficient, there is no need to open the market, or the social welfare will be hurt.

(2) Effect of $m$ and $r$ on sw

This subsection investigates the effect of $\mathrm{m}$ and $\mathrm{r}$ on social welfare under the equilibrium condition. Whereas

$$
\begin{aligned}
& \frac{\partial s w}{\partial m}=\frac{((n-2) a-2 d(n-1)) r+(-n+1) a+2 m n-m}{2 r-1}, \text { we have: } \\
& \frac{\partial s w}{\partial m}<0 \text { if } m<\frac{((n-2) a-2 d(n-1)) r+(-n+1) a}{2 n-1} \\
& \frac{\partial s w}{\partial m}>0 \text { if } m>\frac{((n-2) a-2 d(n-1)) r+(-n+1) a}{2 n-1} \\
& \text { s.t. } r a-2 d r-a+d+m>0, n<\frac{(a-d)(r a-2 d r-a+d+m)}{1-2 r}+1
\end{aligned}
$$


Through the above analysis, it can be seen that the improvement of public-school efficiency may not boost social welfare in a certain range and even cause reduction of social welfare. This is attributable to two reasons: For one thing, the public school may give up more market shares due to the low efficiency; for the other, the $\mathrm{m}$-sw relationship is distorted by the irrational number of schools in the market. Taking $\mathrm{n}=4$ for example, the m-sw relationship in this case can be expressed as Figure 3.

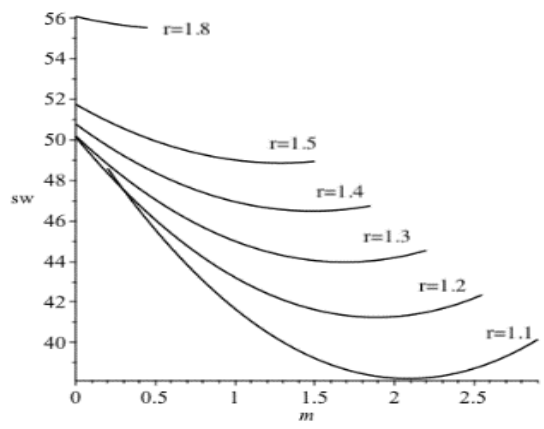

(a) Different $r$ values $(n=4)$

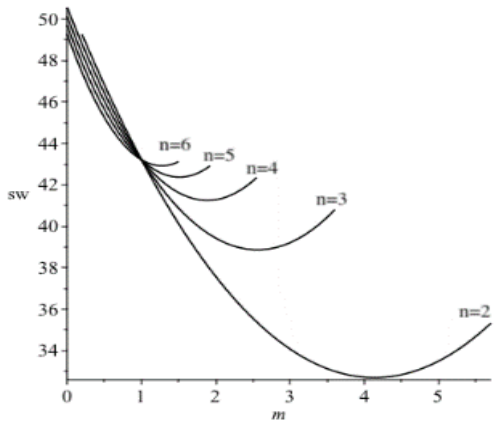

(b) Different $\mathrm{n}$ values $(\mathrm{r}=1.2)$

Figure 3. The m-sw relationship

Since

$\frac{\partial s w}{\partial r}=\frac{\left(r^{2}-r\right) a^{2}+(m n-d(n-1)) a+2 m\left(\left(-n+\frac{1}{2}\right) m+d(n-1)\right)}{(2 r-1)^{2}}$,

the $\frac{\partial s w}{\partial r}<0$ only appears in a certain interval when $\mathrm{m}$ is sufficiently small and the externality is relatively weak, but the decline is rather limited; with the increase of $r$, the value of $\frac{\partial s w}{\partial r}$ will increase rapidly. Overall, $s w$ peaks at the maximum value of $r$ (Figures 4 and 5).

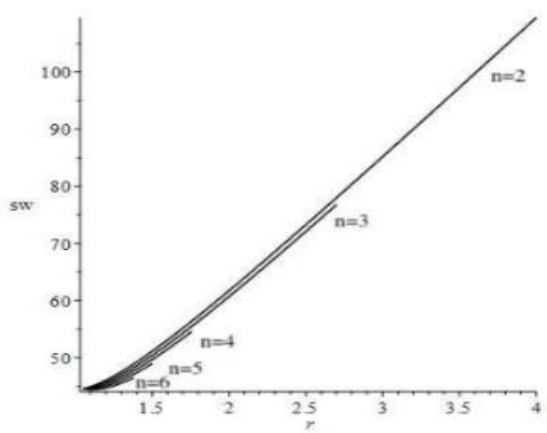

(a) $\mathrm{m}=0.6$

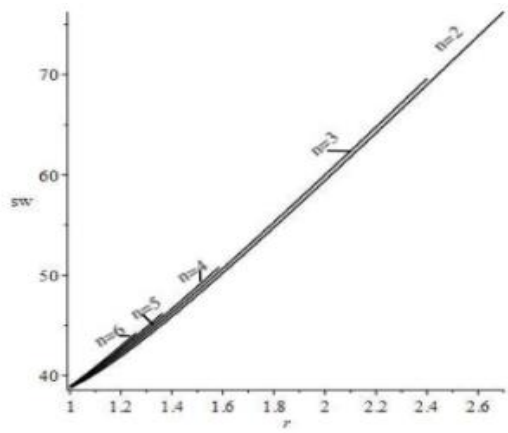

(b) $\mathrm{m}=1.2$

Figure 4. The r-sw relationship at different $\mathrm{n}$ values 


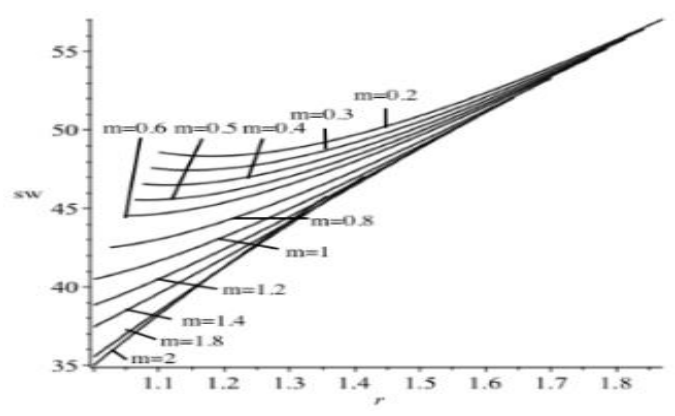

Figure 5. The r-sw relationship at different $\mathrm{m}$ values

From the above, it can be inferred that elementary education and other industries with strong externalities have a significant effect on the promotion of social welfare. Hence, efforts should be paid to develop the public school and enhance its operation efficiency. However, the increase in externality will reduce social welfare if the market features a constant number of competitors, highly efficient public schools, and low externality, for the $\mathrm{m}$-sw relationship is distorted by too many competitors.

Proposition 2: In general, the higher the efficiency of the public school or the greater the externality, the higher the social welfare. However, the correlation is negative in a certain interval, owing to the special goal of the public school or the irrational number of market competitors.

\section{Conclusion}

Based on the mixed oligopoly model, this paper analyses the Cournot competition in a mixed oligopolistic education market of one public school and n-1 private schools, examines the impact of $n$ on the total social welfare, aiming to gain new insights into the government's regulation of market access. Through the research, it is discovered that (1) the number of private schools in the market has a significant impact on the social welfare. The education market should be opened as much as possible without sacrificing the profitability of private schools if the public school is less efficient than private ones; strict access regulation should be implemented to prevent the market distortion of private schools if the public school is very efficient; no regulation is needed if the public school is as efficient as private ones. (2) The number of competitors in the market is not only controlled by government regulation, but also affected by factors like externality and operational cost. If there is no profit, no private school will enter the market even if the market is fully open. Therefore, the government must consider all relevant factors and conduct scientific pre-assessment before determining the number of schools in the market. (3) In general, the higher the efficiency of the public school or the greater the externality, the higher the social welfare. However, the correlation is negative in certain conditions owing to the special goal of the public school or the irrational number of market competitors. These phenomena further highlight the importance of the government's access regulation. 
The above findings shed new light on the government regulation on education market access, especially for developing countries like China. As the largest education consumer in the world, China has greatly opened its education market since the reform and opening-up. Once monopolized by the state, China's education market is now thronged with private capital. Currently, the market segments of elementary, secondary, higher and vocational education are under mixed oligopoly competition, and the mixed ownership is being explored for vocational education. In this process, vicious competition has occurred between private schools. Similarly, chaos in education market are commonly seen in other developing countries after the entry of private schools. According to our conclusions, the vicious competition and chaotic market can be attributed to the lack of effective regulation of market access. Under the premise of fairness and efficiency, the government should establish a scientific market access standard, raise the threshold for market entry and prevent the disordered competition according to the externalities of different educational fields.

\section{References}

Anderson, SP., de Palma, A. \& Thisse, J. F. (1997). Privatization and efficiency in a differentiated industry. European Economic Review, 41(7), 1635-1654. https://doi.org/10.1016/S0014-2921(97)00086-X.

Ashley, L. D., Mcloughlin, C., \& Aslam, M. (2014). The role and impact of private schools in developing countries. Department for International Development, London.

Baird, R. (2009). Private schools for the poor: development, provision, and choice in India. Gray Matters Capital.

Baum, D. R., Cooper, R., \& Lusk-Stover, O. (2018). Regulating market entry of low-cost private schools in sub-saharan africa: towards a theory of private education regulation. International Journal of Educational Development, 60, 100-11. https://doi.org/10.1016/j.ijedudev.2017.10.020.

Chumacero, R., \& Paredes, R. (2008). Should for-profit schools be banned? (No. 15099), MPRA Paper, MPRA, Munich.

De Fraja, G. \& Delbono, F. (1989). Alternative strategies of a public enterprise in oligopoly. Oxford Economic Papers, 41, 302-311. https://doi.org/10.1093/oxfordjournals.oep.a041896

Dixon, P. (2012). Why the denial? Low-cost private schools in developing countries and their contributions to education. Econ Journal Watch Econ. J. Watch, 9, 186-209.

Estrin, S., \& Perotin, V. (1991). Does ownership always matter. International Journal of Industrial Organization, 9(1), 55-72. https://doi.org/10.1016/0167-7187(91)90005-6.

Fielden, J., \& LaRocque, N. (2009). The evolving regulatory context for private education in emerging economies (No. 154), World Bank Working Paper Series. The World Bank, Washington, D.C.

George, K., \& La, Manna, M.M.A. (1996). Mixed duopoly, inefficiency, and public ownership. Review of Industrial Organization, 11(6), 853-860. https://doi.org/10.1007/BF00174411.

Ginsburg, M., Brady, K., Draxler. (2012). Public-private partnerships and the global reform of education in less wealthy countries: a moderated discussion. Comparative Education Review, 56, 155-175. https://doi.org/10.1086/662684. 
Härmä, J. (2011). Education sector support programme in nigeria (ESSPIN) assignment report: study of private schools in Lagos. Rep. No. LG: 303. UKAID.

Härmä, J., \& Adefisayo, F. (2013). Scaling up: The challenges facing low-fee private schools in the slums of Lagos, Nigeria. Low-Fee Priv. Sch. Aggravating Equity or Mitigating Disadv.

Heyneman, S. P., \& Stern, J. M. B. (2014). Low cost private schools for the poor: what public policy is appropriate, International Journal of Educational Development, 35(1), 3-15. https://doi.org/10.1016/j.ijedudev.2013.01.002.

Hill, C. D., Welsch, D. M. (2009). For-profit versus not-for-profit charter schools: an ex- amination of Michigan student test scores. Education Economics. 17, 147-166. https://doi.org/10.1080/09645290801977017.

Jain, R. \& Pal, R. (2012). Mixed duopoly, cross-ownership and partial privatization. Journal of Economics, 107(1), 45-70. https://doi.org/10.1007/s00712-011-0260-6.

Matsumura, T. (1998). Partial privatization in mixed duopoly. Journal of Public Economics, 70(3), $473-483$. https://doi.org/10.1016/S0047-2727(98)00051-6.

Megginson, W. L. \& Netter, J. M. (2001). From state to market: a survey of empirical studies on privatization. Journal of Economic Literature, 39(6), 321- 389. https://doi.org/10.1257/jel.39.2.321.

McLoughlin, C. (2013). Low-cost private schools: evidence, approaches and emerging issues EPS-PEAKS Top. Guid. DFID, London.

Menashy, F. (2014). Theorizing privatization in education: comparing conceptual frameworks and the value of the capability approach. Current Issues in Comparative Education. 16, 13-25.

Nguyen, Q., \& Raju, D. (2014). Private school participation in Pakistan. World Bank Policy.

Phillipson, B., Shukla, S. \& Joshi, P. (2008). Low-Cost private education: Impacts on achieving universal primary education. Commonwealth Secretarial, London.

Robertson, S. L., \& Dale, R. (2013). The social justice implications of privatisation in education governance frameworks: a relational account. Oxford Review of Education, 39(4), 426-445. https://doi.org/10.1080/03054985.2013.820465.

Shleifer. A., \& Vishny. R. W. (1994). Politicians and firms. Quarterly Journal of Economics, 109(4), 995-1025 https://doi.org/10.2307/2118354.

Singh, N., \& Vives, X. (1984). Price and quantity competition in a differentiated duopoly. Rand Journal of Economics, 15, 546-554. https://doi.org/10.2307/2555525.

Singh, K. (2015). Protecting the right to education against commercialization. Report of the Special Rapporteur on the Right to Education. United Nations, Geneva.

Tooley, J. (2009). The Beautiful Tree: A Personal Journey into How the World's Poorest People are Educating Themselves. Cato Institute, Washington, DC.

Tooley, J. \& Dixon, P. (2006). 'de facto' privatisation of education and the poor: implications of a study from sub-saharan Africa and India. Compare A Journal of Comparative and International Education, 36(4), $443-$ 462. https://doi.org/10.1080/03057920601024891.

Verger, A., Bonal, X., \& Zancajo, A. (2016). What is the role and impact of public-private partnerships in education, a realist evaluation of the chilean education quasi-market. Comparative Education Review, 60(2), 223-248. https://doi.org/10.1086/685557. 